\title{
Is Comprehensive Income Superior To Net Income In Equity Valuation? Evidence From The Capital Market Of Kuwait
}

Mostafa A. Elshamy, Kuwait University, Kuwait

Husain Y. Alyousef, Kuwait University, Kuwait

Jassem Al- Mudhaf, Kuwait University, Kuwait

\begin{abstract}
The study examines whether comprehensive income numbers reported under International Financial Reporting Standards (IFRS) have value relevance over net income in equity valuation. We use a sample of firms that are listed in Kuwait Stock Exchange from banking, investment, real estate, industrial, basic materials, telecommunications, consumer services, oil \& gas and health care sectors during the years 2012-2015.

The study applies a methodology used by Collins, Maydew and Weiss (1997) that is based on Ohlson (1995) equity valuation model and Theil (1971) technique to measure and compare the relative and the incremental explanatory power of comprehensive income and net income. The study provides evidence that comprehensive income is not superior to net income in equity valuation. Reporting other comprehensive income gains and losses as elements of the income statement produces a measure of earnings that decreases the explanatory power of the valuation model; decreases the incremental information content of earnings. Other comprehensive income gains and losses when added as an explanatory variable to the valuation model did not enhance significantly its explanatory power.

The results we obtained supports the current requirement by the IFRS and US GAAP of deferring other comprehensive gains and losses and contributes to the literature on the value relevance of other comprehensive income gains and losses in emerging capital markets.
\end{abstract}

Keywords: Equity Valuation; Reporting Comprehensive Income; Value Relevance; Other Comprehensive Income Gains and Losses

\section{INTRODUCTION}

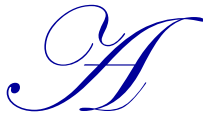

ccording to current IFRS, certain gains and losses termed as other comprehensive income items are not included in the determination of net income and accumulated in the shareholders' equity section of the statement of financial position until they are realized. These items include five types: Gains and losses from the revaluation of certain types of investment in marketable securities (IAS 39 \& IFRS 9); changes in the fair value of the hedging instruments in cash flow hedges (IAS 39 and IFRS 9); gains and losses on translation of financial statements of net investment in foreign entities (IAS 21); gains and losses from re-measurements of the net defined benefit asset or liability (IAS 26); and gains and losses from revaluation of property, plant and equipment (IAS 16) ${ }^{1}$.

Under IAS 1 (revised 2007), profit or loss (will be referred to as net income) and other comprehensive income gains and losses might be presented either in: (a) A single statement containing two sections, the first for net income and the second for comprehensive income; or (b) Two statements: A statement shows the elements of net income (income statement) and a another statement of comprehensive income that start with net income and display the items of other comprehensive income gains and losses. In addition, the section of other comprehensive income should present line

${ }^{1}$ Under US GAAP other comprehensive income includes the first four items only. 
items for the amount for the period of each other comprehensive income item. The items should be classified by their nature and grouped between those items that will or will not be reclassified subsequently to net income (IAS 1 revised 2007, Par.82 A).

Advocate of deferring other comprehensive income items as currently required by IFRS claim that these items are mostly transitory items and therefore will have limited value in predicting future performance and will not be useful to users of financial statement in making rational investment and credit decisions. Net income under this approach would be more useful to investors because it provides a better indication of future performance and is a good predictor of future cash flows and consequently a good determinant of the value of firms (Rees \& Shan, 2012).

Proponents of including other comprehensive items in net income on the other hand, contend that income measured under this approach will be less subject to earnings management, more consistent with the concept of articulation of the income statement and the statement of financial position, and more in accordance with the equity valuation theory (Feltham \& Ohlson, 1995).

Choosing whether to include other comprehensive income gains and losses as elements of net income or to defer them is not simple and further empirical studies are needed to examine their value relevance.

The primary objective of the current study is to examine if other comprehensive income items recognized under (IFRS) have any role in explaining stock prices for Kuwaiti companies listed in Kuwait Stock Exchange. In other words, the study investigates if comprehensive income is relatively more associated with market price than net income using a methodology developed by Collins et al. (1997) that is based on Ohlson (1995) equity valuation model and Theil (1971) technique. This methodology has been used extensively by prior studies (see e.g., Collins, Pincus and Xie 1999; Elshamy \& Kayed, 2005; El Shamy, Al-Hajri, and Al-Bassam 2014; and Kanagaretnam, Mathieu and Shehata 2009) to assess the impact of including other comprehensive income on net income on its incremental explanatory power for stock prices.

The empirical results indicate that net income is more suitable than comprehensive income in equity valuation and the incremental information content of net income is higher than that of comprehensive income. In addition, other comprehensive income items did not significantly enhance the explanatory power of the valuation model when added as an explanatory variable.

The results obtained provide evidence that other comprehensive income gains and losses in aggregate have no marginal information content over net income in explaining stock prices. These results have important implication for the International Accounting Standards Board (IASB) and the Financial Accounting Standard Board (FASB) and support their current reporting position to defer other comprehensive income gains and losses until they are realized.

The rest of the paper is organized as follows: Section 2 review the literature related to examining the relevance of reporting other comprehensive income gains and losses, section 3 presents the sample selection and the research design, section 4 contains the empirical results. Finally, section 5 summarizes the results and concludes the paper.

\section{LITERATURE REVIEW}

Several studies have attempted to answer the question, "Is there a difference in the value relevance of net income to that of comprehensive income?" The attempt to answer this question has dominated the literature in previous years, especially after the implementation of SFAS 130 in 1997 in USA and the worldwide adoption and application of IAS 1 (revised 2007). The main objective of these studies was to examine the value relevance of other comprehensive income gains and losses that has been disclosed under these standards hoping that the results obtained will help standard setters in their effort to improve financial statement presentation.

Dhaliwal, Subramanyam, and Trezevant (1999) tested whether stock return is more associated with net income or comprehensive income. The authors conducted their study using all firms included in the CMPUSTAT and CRSP databases for the years 1994-1995. The results concluded that that: compressive income was not more strongly associated with market returns than net income; the association between comprehensive income and market prices is 
weaker than the association between net income and market prices; and net income predicts both future cash flows and future net income better than comprehensive income.

More recent studies by Pronobis and Zulch (2010) and Barton, Hansen and Pownall (2010) confirmed Dhaliwal et al. (1999) conclusion. They compared the ability of comprehensive income and net income to predict future net income and cash flows and didn't find any superiority to comprehensive income over net income.

Kanagaretnam et al. (2009) on the other hand, reached a different conclusion. They examined whether disclosing comprehensive income as required by the Canadian Accounting Standard Board (AcSB) have value relevance over net income. The authors used data for Canadian firms listed in both New York Stock Exchange and Toronto Stock Exchange covering the period from 1998 to 2003. The authors documented that unrealized gains and losses from investment in securities classified as available-for-sale and unrealized gains and losses recognized from cash flow hedges, are associated with both stock prices and stock return. The association with stock prices and stock return becomes even stronger with the aggregated comprehensive income than with net income. Moreover, they documented that comprehensive income is superior to net income in predicting both future net income and cash flows.

Biddle and Choi (2006) study compares the usefulness of four measures of income across three different applications. The income measures used are: The traditional net income; net income after extraordinary items and discontinued operations; the SFAS definition of comprehensive income; and a broad measure of net income which includes common stock dividends and changes in retained earnings. The three applications for decision usefulness include: information content, predictive ability and executive compensation.

The authors reached mixed results. The results for the information content application, revealed that SFAS definition of comprehensive income is more useful than both the traditional net income and the broad definition of income. For the predictive ability application, none of the income measures was clearly more useful for predicting future operating income. However, the broad measure of income was more useful in predicting itself and future traditional net income. SFAS definition of comprehensive income is better predictor of itself. Finally, traditional net income was superior in predicting cash flows. As for the executive compensation application, traditional net income proved to be the most useful measure.

Jones and Smith (2011) examined the value relevance, predictive values and persistence of other comprehensive income (OCI) gains and losses using a sample of 236 US firms during the 1986-2005 period and found that OCI gains and losses have low value relevance, negative persistence and low predictive value. They further compared OCI gains and losses to other gains and losses denoted as special items and included in the determination of net income under current GAAP in terms of the above mentioned three aspects and documented that: Special items gains and losses have higher value relevance; they are transitory while OCI gains and losses exhibit negative persistence; and OCI gains and losses have weaker predictive values for forecasting both future cash flows and net income.

Another stream of research compares the usefulness of reporting OCI gains and losses in a separate statement of financial performance, as required by the recent movement by the IASB and the FASB as opposed to reporting them in the statement of changes in stockholders' equity and reached mixed conclusions.

An early study by Hirst and Hopkins (1998) found that reporting OCI gains and losses in a separate statement of financial performance increased the analyst's ability to detect earning management and reduced the influence of earning management on her/his valuation as opposed to when they are reported in the statement of changes in shareholders' equity.

Maines and McDaniel (2000) supported Hirst and Hopkins results. They conducted an experimental study to test if the format of presenting OCI gains and losses will have an effect on nonprofessional investors processing information about the volatility of the unrealized gains and losses on the available for sale investment in marketable securities. They concluded that judgment of nonprofessional investors on the performance of corporations and managers would reflects the volatility of OCI gains and losses only when it is disclosed in a separate statement of performance but not when reported in the statement of changes in shareholders' equity. 
Lee, Petroni and Shen (2006) provided evidence from the property-liability insurance industry that including OCI gains and losses in a separate performance statement would decrease the likelihood of management engagement in earning management and will consequently deter management opportunistic activities and provide information in more transparent format to the investors.

On the other hand, Chambers, Linsmeier, Shakespeare, and Sougiannis (2007); Lin, Martinez and Wang (2016); reached contradicting results. Chambers et al. (2007) found that including OCI gains and losses in the statement of changes in shareholders' equity rendered a better use of information by the investors due to their familiarity with this location.

Lin et al. (2016) examined whether shifting the location of reporting OCI items from the statement of changes in shareholders' equity to a separate performance statement has affected the value relevance of OCI gains and losses. They found that changing the location of reporting these items affects their value relevance. More specifically, they found that changing the reporting location by firms from the statement of changes in shareholders' equity to a separate performance statement decreased their value relevance when compared to firms that did not change the reporting location. They also found that the market prices aggregate OCI only if it is presented in the statement of shareholders' equity.

From the previous review, one can conclude that mixed evidence on the usefulness of OCI gains and losses was reached by the previous empirical studies regardless of the research method they used. Consequently, in order to answer the question asked at the beginning of this section in a more substantive manner, there is a need to reformulate the question by asking more specifically, "When and why there is a difference in the value relevance of net income to that of comprehensive income?"

In an effort to answer this more precise question, we need to expand the research to include different types of markets and settings. Therefore, we investigate the Kuwaiti market as a new context that might add to the existing research.

Kuwait Stock Market (KSE) is regulated by the Kuwaiti government through different regulatory bodies: Capital Market Authority, the Ministry of Finance, the Ministry of Commerce and industry, and the Central Bank of Kuwait. KSE Market was officially operated in 1984 and it is considered one of the largest stock markets in the Middle East in terms of market capitalization. All listed KSE firms must comply with the IASB reporting requirements since 1992.

\section{SAMPLE SELECTION AND RESEARCH DESIGN}

\subsection{Sample Selection}

The data used for the study belongs to all Kuwaiti firms from banking, investment, real estate, industrial, basic materials, telecommunications, consumer services, oil and gas and health care sectors that are listed in Kuwait stock exchange (KSE) during years 2012-2015 for which share prices, book values, comprehensive income and net income were available during the 4 year period. Observations that has zero other comprehensive income were deleted from the analysis. The process yielded a total sample of 435 observations during the study period.

\subsection{The Research Design}

Our research design is based on the empirical implication function of Ohlson (1995) model that expresses the value of the equity for the equity of a firm as a function of both its book value and earnings.

$P P S_{i t}=a_{0}+a_{2} B V P S_{i t}+a_{1} E P S_{i t}+e_{i t}$

Where:

PPS $_{\text {it }}=$ stock price of firm I at the end of year $\mathrm{t}$.

BVS $_{\text {it }}=$ book value per share for firm $\mathrm{i}$ at the end of period $\mathrm{t}$.

EPS $_{\text {it }}=$ Earnings per share (the basic EPS) for firm i during period $t$.

$\mathrm{e}_{\mathrm{it}} \quad=$ the error term 
To compare the explanatory power that BVS and EPS have in relation to stock prices, Collins et al. (1997) methodology is used to decompose the coefficient of determination (Adjusted $\mathrm{R}^{2}$ (EPS, BVS)) obtained from equation 1 , which measure the combined explanatory power of BVS and EPS into three components: (1) the incremental explanatory power of BVS, (2) the incremental explanatory power of EPS, and (3) the incremental explanatory power common to both BVS and EPS. In order to calculate these three components, the following two equations will be estimated:

$$
\begin{aligned}
& P P S_{i t}=b_{0}+b_{1} E P S_{i t}+e_{i t} \\
& P P S_{i t}=c_{0}+c_{1} B V S_{i t}+e_{i t}
\end{aligned}
$$

The coefficient of determination obtained from equations 2 and 3 measures the explanatory power that each of earnings per share and book value per share has for price per share and will be denoted adjusted $\mathrm{R}^{2}$ (EPS) and adjusted $\mathrm{R}^{2}$ (BVS), respectively.

The incremental explanatory power provided by EPS (Incr. EPS) is measured by the difference between adjusted $\mathrm{R}^{2}$ (EPS, BV) and adjusted $\mathrm{R}^{2}$ (BVS). Similarly, the incremental explanatory power provided by book value (Incr. BVS) is measured by the difference between adjusted $\mathrm{R}^{2}$ (EPS, BVS) and adjusted $\mathrm{R}^{2}$ (EPS). The remaining $\mathrm{R}^{2}$ (EPS, BVS) - Incr. EPS Incr. BVS is donated as Incr. COM is used as the explanatory power common to both EPS and BVS.

To examine whether comprehensive income provides more information content than net income in equity valuation, both equations 1 and 2 are estimated twice, firstly using net income (net income per share, NIPS) as a measure of earnings (will be referred to in the following section as equations 1.1 and 2.1), and secondly by using comprehensive income (Comprehensive income per share, CIPS) as a competing measure of earnings (will be referred to as equations 1.2 and 2.2 in the following section). The total explanatory value of the valuation models using the two different measures of earnings as measured by the coefficient of determination (Adjusted $\mathrm{R}^{2}$ ) is compared as well as their incremental explanatory values (Incr. NIPS and Incr. CIPS). If comprehensive income provides more information content than net income in equity valuation, we expect that using CIPS as a measure of earnings will result in a higher coefficient of determination and a higher incremental explanatory power than those obtained by using NIPS.

To further investigate whether stock prices reflect any incremental information that other comprehensive income items have over net income and book value, we investigate if adding other comprehensive income per share as an additional independent variable to the original valuation model (equation 1) would increase its explanatory value. The following version of the valuation model will be estimated:

$P P S_{i t}=a_{0}+a_{2}$ BVS $_{i t}+a_{1}$ NIPS $_{i t}+$ OCIPS $_{i t}+e_{i t}$

Where PPS $\mathrm{it}_{\mathrm{t}}=$ firm i's stock price at the end of year $\mathrm{t} ; \mathrm{BVS}_{\mathrm{it}}=$ book value per share for firm $\mathrm{i}$ at the end of period $\mathrm{t}$, NIPS $i t=$ net income per share for firm $i$ during period $t$; and OCIPS ${ }_{i t}$ is other comprehensive income per share for firm i during period $t$.

If other comprehensive income has any value relevance in equity valuation, we expect the coefficient of OCIPSit to be significantly positive and the coefficient of determination of equation 4 to exceeds that of equation 1.1.

To control for any possible effect of negative comprehensive income on the results, we partition the total sample into two subsamples based on the sign of other comprehensive income and re-examine if comprehensive income is superior to net income using the same methods described in this section.

\section{THE EMPIRICAL RESULTS}

\subsection{Descriptive Statistics}

Summery Statistics and correlations matrix for the variables used in the study sample are presented in Table 1. Panel A shows that the mean and the standard deviation of comprehensive income per share are higher than those for net 
income per share. Panel B shows that book value per share; net income per share, and comprehensive income per share are positively correlated with market prices as expected; net income per share is more highly correlated with stock price than comprehensive income per share; and book value per share is more highly correlated with stock prices than net income per share and comprehensive income per share. The correlation between other comprehensive income per share and stock prices is negative and insignificant.

\subsection{The Association between Prices, Book Values and Net Income}

The results of estimating equations 1.1, 2.1 and 3 are presented in Panel A of table 2. The results for equation 1.1 show that the coefficients on book value per share and net income per share are positive and significant at the $1 \%$ level for all years. The adjusted $\mathrm{R}^{2}$ (NIPS\&BVS) shows strong association between market price and book value per share and net income per share. Book value per share and net income per share explain about $53 \%, 64 \%, 75 \%, 62 \%$ and $64 \%$ of the cross-sectional variation in securities' prices during years 2012, 2013, 2014, 2015 and for the total of the firm-year observations, respectively.

The simple regression results of equations 2 and 3 show that the coefficient of net income per share and book value per share are significant at the $1 \%$ level and each of them explains a significant portion of the variations in stock prices. Net income per share explains approximately $36 \%, 38 \%, 57 \%, 57 \%$ and $49 \%$ of the cross-sectional variation in securities prices. Book value per share explains approximately $45 \%, 59 \%, 70 \%, 53 \%$ and $57 \%$ respectively of the cross-sectional variation in securities' prices for the years of the study.

Table 1. Descriptive Statistics and Correlation Matrix

\begin{tabular}{l|c|c|c|c|c}
\hline \multicolumn{1}{l|}{ Panel A: Descriptive Statistics ${ }^{\text {a }}$} \\
\multicolumn{1}{c|}{ Variable } & $\mathbf{N}$ & Mean & $\begin{array}{c}\text { Standard } \\
\text { Deviation }\end{array}$ & Min. & Max. \\
\hline NIPS & 435 & 0.0094 & 0.020 & -0.050 & 0.102 \\
\hline CIPS & 435 & 0.010 & 0.025 & -0.052 & 0.224 \\
\hline BVS & 435 & 0.188 & 0.136 & 0.024 & 0.859 \\
\hline OCIPS & 435 & 0.001 & 0.009 & -0.072 & 0.048 \\
\hline PPS & 435 & 0.184 & 0.217 & 0.012 & 1.300 \\
\hline
\end{tabular}

\begin{tabular}{l|c|c|c|c|c}
\multicolumn{2}{l}{ Panel B: Correlation Matrix } \\
\multicolumn{1}{|c|}{ Variable } & NIPS & CIPS & BVS & OCIPS & PPS \\
\hline NIPS & 1 & $0.839^{* *}$ & $0.655^{* *}$ & 0.050 & $0.699^{* *}$ \\
\hline CIPS & - & 1 & 0.569 & $0.341^{* *}$ & $0.573^{* *}$ \\
\hline BVS & - & - & 1 & 0.061 & $0.757^{*}$ \\
\hline OCIP & & & & 1 & -0.003 \\
\hline PPS & - & - & - & & 1 \\
\hline
\end{tabular}

${ }^{a}$ All value figures are expressed in Kuwaiti Dinar (KD).

Variables are defined as follows:

NIPS = income per share, CIPS = Comprehensive income per share, $\mathrm{BVS}=$ Book value per share, $\mathrm{OCIPS}=$ other comprehensive income per share, and $\mathrm{P}=$ stock price per share,

${ }^{* *}$ Significant at 0.01 . 
Table 2. Tests of the Association between Prices, Book Values and Net Income

\begin{tabular}{|c|c|c|c|c|c|c|c|c|}
\hline \multicolumn{9}{|c|}{ Panel A: The Regression Equations: } \\
\hline \multicolumn{8}{|c|}{$\begin{array}{l}P P S_{i t}=a_{0}+a_{1} B V S_{i t}+a_{2} N I P S_{i t}+e_{i t} \\
P P S_{i t}=b_{0}+b_{1} N I P S_{i t}+e_{i t} \\
P P S_{i t}=c_{0}+c_{1} B V S_{i t}+e_{i t}\end{array}$} & $\begin{array}{r}(1.1) \\
(2.1) \\
(3)\end{array}$ \\
\hline Year & $\mathbf{N}$ & $\mathbf{a}_{1}$ & $\mathbf{a}_{2}$ & $\begin{array}{c}\text { Adj. } \mathbf{R}^{2} \\
\text { (NIPS\&BVS) }\end{array}$ & $\mathbf{b}_{1}$ & $\begin{array}{c}\text { Adj. } \\
\mathbf{R}^{2} \text { (NIPS) }\end{array}$ & $\mathbf{c}_{1}$ & $\begin{array}{c}\text { Adj. } \\
\mathbf{R}_{(\mathbf{B V S})}\end{array}$ \\
\hline 2012 & 86 & $\begin{array}{c}0.486 \\
\left(5.451^{* *}\right)\end{array}$ & $\begin{array}{c}0.343 \\
\left(3.385^{* *}\right)\end{array}$ & 0.525 & $\begin{array}{c}0.608 \\
\left(7.019^{* *}\right)\end{array}$ & 0.362 & $\begin{array}{c}0.673 \\
\left(8.343^{* *}\right)\end{array}$ & 0.447 \\
\hline 2013 & 112 & $\begin{array}{c}0.615 \\
\left(8.846^{* *}\right)\end{array}$ & $\begin{array}{c}0.272 \\
\left(3.910^{* *}\right)\end{array}$ & 0.635 & $\begin{array}{c}0.620 \\
\left(8.279^{* *}\right)\end{array}$ & 0.378 & $\begin{array}{c}0.769 \\
\left(12.609^{* *}\right)\end{array}$ & 0.587 \\
\hline 2014 & 119 & $\begin{array}{c}0.607 \\
\left(9.287^{* *}\right)\end{array}$ & $\begin{array}{c}0.325 \\
\left(4.965^{* *}\right)\end{array}$ & 0.748 & $\begin{array}{c}0.754 \\
\left(12.420^{* *}\right)\end{array}$ & 0.565 & $\begin{array}{c}0.837 \\
\left(16.524^{* *}\right)\end{array}$ & 0.697 \\
\hline 2015 & 118 & $\begin{array}{c}0.365 \\
\left(4.089^{* *}\right)\end{array}$ & $\begin{array}{c}0.476 \\
\left(5.325^{* *}\right)\end{array}$ & 0.621 & $\begin{array}{c}0.757 \\
\left(12.489^{* *}\right)\end{array}$ & 0.570 & $\begin{array}{c}0.732 \\
\left(11.571^{* *}\right)\end{array}$ & 0.532 \\
\hline All years & 435 & $\begin{array}{c}0.525 \\
\left(13.595^{* *}\right)\end{array}$ & $\begin{array}{c}0.350 \\
\left(9.065^{* *}\right)\end{array}$ & 0.640 & $\begin{array}{c}0.699 \\
\left(20.312^{* *}\right)\end{array}$ & 0.487 & $\begin{array}{c}0.757 \\
\left(24.112^{* *}\right)\end{array}$ & 0.572 \\
\hline
\end{tabular}

Panel B: The Incremental Explanatory Power of Net Income and Book Values:

Incr. NIPS $=$ Adj. $R^{2}$ (NIPS \&BVS) - Adj. $R^{2}$ (BVS)

Incr. BVS $=$ Adj. $R^{2}$ (NIPS\&BVS) - Adj. $R^{2}$ (NIPS)

Incr. $\mathrm{COM}=\mathrm{Adj} . \mathrm{R}^{2}$ (NIPS \&BVS) - Incr. NIPS - Incr. BVS

\begin{tabular}{c|c|c|c|c|c|c|c|}
\hline Year & $\begin{array}{c}\text { Adj. } \mathbf{R}^{\mathbf{2}} \\
\text { (NIPS\&BVS) }\end{array}$ & ${\text { Adj. } \mathbf{R}^{\mathbf{2}} \text { (NIPS) }}^{\text {Adj. } \mathbf{R}^{\mathbf{2}} \text { (BVS) }}$ & Incr. NIPS & Incr. BVS & $\begin{array}{c}\text { Incr. } \\
\mathbf{C O M}\end{array}$ \\
\hline 2012 & 0.525 & 0.362 & 0.447 & 0.078 & 0.163 & 0.284 \\
\hline 2013 & 0.635 & 0.378 & 0.587 & 0.048 & 0.257 & 0.330 \\
\hline 2014 & 0.748 & 0.565 & 0.697 & 0.051 & 0.183 & 0.514 \\
\hline 2015 & 0.621 & 0.570 & 0.532 & 0.089 & 0.051 & 0.481 \\
\hline All years & 0.640 & 0.487 & 0.572 & 0.068 & 0.153 & 0.419 \\
\hline
\end{tabular}

** Significant at 0.01 level.

The results of estimating the incremental explanatory power of net income and book value in Panel B show that the incremental explanatory power of net income per share (Incr. NIPS) is approximately $8 \%, 5 \%, 5 \%, 9 \%$ and $7 \%$ and the incremental explanatory power of book value per share (Incr. BVS) is approximately $16 \%, 26 \%, 18 \%, 5 \%$ and $15 \%$ for years 2012, 2013, 2014, 2015 and for all years, respectively.

\subsection{The Association between Prices, Book Values and Comprehensive income}

Panel A of table 3 presents estimates of equations 1.2, 2.2 and 3. The results of equation 1.2 demonstrate a significant association between stock prices and book values per share plus comprehensive income per share during each year and for all years combined. The coefficient of comprehensive income per share and book values per share are positive and significant at the 0.01 level. The adjusted $\mathrm{R}^{2}$ (CIPS\&BVS) indicates that book values per share and comprehensive income per share explain about $52 \%, 62 \%, 73 \%, 54 \%$ and $60 \%$ of the cross-sectional variation in securities prices during years 2012, 2013, 2014, 2015 and all years combined, respectively.

The estimates of equations 2 show that comprehensive income per share has a significant positive coefficient at the $1 \%$ level and explains approximately $32 \%, 35 \%, 40 \%, 28 \%$ and $34 \%$ of the cross-sectional variation in securities prices during all years 2012, 2013, 2014, 2015 and all firm-year observations, respectively.

The results of decomposing the adjusted $\mathrm{R}^{2}$ (CIPS\&BVS) into its three incremental explanatory power components are shown in Panel B. The incremental explanatory power of comprehensive income per share (Incr. CIPS), is approximately $7 \%, 3 \%, 3 \%, 9 \%$ and $3 \%$; the incremental explanatory power of book value per share (Incr. BV) is approximately $19 \%, 27 \%, 40 \%, 26 \%$ and $26 \%$; and the incremental explanatory power common to both comprehensive income per share and book value per share (Incr. COM) is approximately $25 \%, 31 \%, 30 \%, 28 \%$ and $31 \%$ for years 2012, 2013, 2014, 2015 and for all years combined, respectively. 
Table 3. Tests of the Association between Prices, Book Values and Comprehensive Income

\begin{tabular}{|c|c|c|c|c|c|c|c|c|}
\hline \multicolumn{9}{|c|}{ Panel A: The Regression Equations: } \\
\hline $\begin{array}{l}P P S_{i t}=a_{0} \\
P P S_{i t}=b_{0} \\
P P S_{i t}=c_{0}\end{array}$ & $\begin{array}{l}B V S_{i t} \\
C I P S_{i} \\
3 V S_{i t}\end{array}$ & $\operatorname{cips}_{i t}+e_{i t}$ & & & & & & $\begin{array}{r}(1.1) \\
(2.1) \\
(3)\end{array}$ \\
\hline Year & $\mathbf{N}$ & $\mathbf{a}_{1}$ & $\mathbf{a}_{2}$ & $\begin{array}{c}\text { Adj. } \mathbf{R}^{2} \\
\text { (CIPS\&BVS) }\end{array}$ & $\mathbf{b}_{1}$ & $\begin{array}{c}\text { Adj.:R } \\
\text { (CIPS) }\end{array}$ & $\mathbf{c}_{1}$ & $\begin{array}{c}\text { Adj. } \\
\text { (BVS) }\end{array}$ \\
\hline 2012 & 86 & $\begin{array}{c}0.514 \\
\left(5.883^{* *}\right)\end{array}$ & $\begin{array}{r}.0 .316 \\
\left(3.615^{* *}\right)\end{array}$ & 0.516 & $\begin{array}{c}0.575 \\
\left(6.439^{* *}\right)\end{array}$ & .323 & $\begin{array}{c}0.673 \\
\left(8.343^{* *}\right)\end{array}$ & 0.447 \\
\hline 2013 & 112 & $\begin{array}{c}0.640 \\
\left(8.918^{* *}\right)\end{array}$ & $\begin{array}{c}0.224 \\
\left(3.127^{* *}\right)\end{array}$ & 0.618 & $\begin{array}{c}0.592 \\
\left(7.711^{* *}\right)\end{array}$ & 0.345 & $\begin{array}{c}0.769 \\
\left(12.609^{* *}\right)\end{array}$ & 0.587 \\
\hline 2014 & 119 & $\begin{array}{c}0.711 \\
\left(11.908^{* *}\right)\end{array}$ & $\begin{array}{c}0.214 \\
\left(3.585^{* *}\right)\end{array}$ & 0.725 & $\begin{array}{c}0.632 \\
\left(8.829^{* *}\right)\end{array}$ & 0.395 & $\begin{array}{c}0.837 \\
\left(16.524^{* *}\right)\end{array}$ & 0.697 \\
\hline 2015 & 118 & $\begin{array}{c}0.644 \\
\left(8.159^{* *}\right)\end{array}$ & $\begin{array}{c}0.144 \\
\left(1.823^{*}\right)\end{array}$ & 0.541 & $\begin{array}{c}0.536 \\
\left(6.845^{* *}\right)\end{array}$ & 0.282 & $\begin{array}{c}0.732 \\
\left(11.571^{* *}\right)\end{array}$ & 0.532 \\
\hline All years & 435 & $\begin{array}{c}0.637 \\
\left(17.292^{* *}\right)\end{array}$ & $\begin{array}{c}0.211 \\
\left(5.727^{* *}\right)\end{array}$ & 0.601 & $\begin{array}{c}0.573 \\
\left(14.559^{* *}\right)\end{array}$ & 0.327 & $\begin{array}{c}0.757 \\
\left(24.112^{* *}\right)\end{array}$ & 0.572 \\
\hline
\end{tabular}

Panel B: The Incremental Explanatory Power of Comprehensive Income and Book Values:

Incr. CIPS $=$ Adj. $R^{2}$ (CIPS \&BVS) - Adj. $R^{2}$ (BVS)

Incr. $B V=$ Adj. $R^{2}{ }_{(C I P S \& B V S)}-$ Adj. $R^{2}{ }_{(C I P S)}$

Incr. $\mathrm{COM}=\mathrm{Adj} . \mathrm{R}^{2}$ (CIPS \&BVS) - Incr. CIPS - Incr. BVS

\begin{tabular}{|c|c|c|c|c|c|c|}
\hline Year & $\begin{array}{c}\text { Adj. R } \\
\text { (CIPS\&BVS) }\end{array}$ & Adj. $R^{2}$ (CIPS) & Adj. $\mathbf{R}_{(B V S)}$ & Incr. CIPS & Incr. BVS & $\begin{array}{l}\text { Incr. } \\
\text { COM }\end{array}$ \\
\hline 2012 & 0.516 & 0.323 & 0.447 & 0.069 & 0.193 & 0.254 \\
\hline 2013 & 0.618 & 0.345 & 0.587 & 0.031 & 0.273 & 0.314 \\
\hline 2014 & 0.725 & 0.395 & 0.697 & 0.028 & 0.395 & 0.302 \\
\hline 2015 & 0.541 & 0.283 & 0.532 & 0.009 & 0.258 & 0.274 \\
\hline All years & 0.601 & 0.327 & 0.572 & 0.029 & 0.274 & 0.300 \\
\hline
\end{tabular}

${ }^{* *}$ Significant at less than 0.01 .

\subsection{Comparing the Value Relevance of Net Income and Comprehensive Income}

A summary of the results taken from tables 2 and 3 related to the overall value relevance and the incremental explanatory power of net income per share and comprehensive income per share are shown in table 4 . Comparing the coefficient of determination (Adj. $\mathrm{R}^{2}$ (NIPS\&BVS)) of equation 1.1 presented in column 2 which uses NIPS as a measure of earnings to that of equation 1.2 presented in column 5 that uses CIPS as a measure of earnings (Adj. $\mathrm{R}^{2}$ (CIPS\&BVS) shows that Adj. $\mathrm{R}^{2}$ (NIPS\&BVS) is higher than Adj. $\mathrm{R}^{2}$ (CIPS\&BVS) in all years. The valuation model explains more (less) of the variation of share prices when net income (comprehensive income) is used as a measure of earnings in all years.

Columns 4 and 7 present the incremental explanatory power of net income per share and comprehensive income per share, respectively. The results reveal that net income per share has higher incremental explanatory power than comprehensive income per share in all years. Net income per share adds more value relevance to the valuation model than comprehensive income per share.

The overall results show that net income per share delivers value relevant information relative to comprehensive income per share, and hence is superior in equity valuation.

\subsection{The Regression Results for the Expanded Valuation Model}

Table 5 contains the estimates of equation 4 which is the original valuation model (equation 1.1) after adding other comprehensive income per share as an additional independent variable. The results show that adjusted $\mathrm{R}^{2}$ from using net income, other comprehensive income and book values (the expanded valuation model) explains approximately $52 \%, 64 \%, 75 \%, 62 \%$ and $64 \%$ of the cross-sectional variation in securities prices during the study period. Comparing these results with the adjusted $\mathrm{R}^{2}$ of $53 \%, 64 \%, 75 \%, 62 \%$ and $64 \%$ obtained from table 2 using the original valuation 
model reveals that adding other comprehensive income items as an extra explanatory variable to the valuation model has no effect on its explanatory.

In addition, the coefficient of other comprehensive income is mostly negative and insignificant in all years except for year 2015. An explanation for the negative coefficient of other comprehensive income might be related to its negative persistence feature as documented by Jones and Smith (2011).

It is clear that other comprehensive income as an aggregate number does not enhance the explanatory value of the valuation model and hence it is irrelevant in equity valuation.

Table 4. Summary of the Relative and Incremental Explanatory Power Results

\begin{tabular}{c|c|c|c|c|c|c}
\hline Year & Adj. $^{\mathbf{2}}$ (NIPS\&BV) & Adj. $_{\text {(NIPS) }}^{\mathbf{2}}$ & Incr. NIPS & Adj. $^{\mathbf{2}}$ (CIPS\&BV) & Adj. $^{\mathbf{2}}$ (CIPS) & Incr. CIPS \\
\hline 2012 & 0.525 & 0.362 & 0.078 & 0.516 & 0.323 & 0.069 \\
\hline 2013 & 0.635 & 0.378 & 0.048 & 0.618 & 0.345 & 0.031 \\
\hline 2014 & 0.748 & 0.565 & 0.051 & 0.725 & 0.395 & 0.028 \\
\hline 2015 & 0.621 & 0.570 & 0.089 & 0.541 & 0.282 & 0.009 \\
\hline All years & 0.640 & 0.487 & 0.068 & 0.601 & 0.327 & 0.029 \\
\hline
\end{tabular}

Table 5. Tests of the Association between Prices, Book Values, Net Income and Other Comprehensive Income

\begin{tabular}{|c|c|c|c|c|c|}
\hline \multicolumn{6}{|l|}{ The Model: } \\
\hline \multicolumn{5}{|c|}{$P P S_{i t}=c_{0}+c_{1} N I P S_{i t}+c_{2} B V S_{i t}+c_{3} O C I P S_{i t}+e_{i t}$} & \multirow[b]{2}{*}{ Adj. $R^{2}$} \\
\hline Year & $\mathbf{N}$ & $\mathrm{C}_{1}$ & $\mathbf{C}_{2}$ & C3 & \\
\hline 2012 & 86 & $\begin{array}{c}0.339 \\
\left(3.742^{* *}\right)\end{array}$ & $\begin{array}{c}0.487 \\
\left(5.427^{* *}\right)\end{array}$ & $\begin{array}{c}0.023 \\
(0.299)\end{array}$ & 0.519 \\
\hline 2013 & 112 & $\begin{array}{c}0.255 \\
\left(3.619^{* *}\right)\end{array}$ & $\begin{array}{c}0.629 \\
\left(8.987^{* *}\right)\end{array}$ & $\begin{array}{c}-0.080 \\
(-1.372)\end{array}$ & 0.638 \\
\hline 2014 & 119 & $\begin{array}{c}0.329 \\
\left(4.967^{* *}\right)\end{array}$ & $\begin{array}{c}0.604 \\
\left(9.162^{* *}\right)\end{array}$ & $\begin{array}{c}-0.022 \\
(-0.471)\end{array}$ & 0.747 \\
\hline 2015 & 118 & $\begin{array}{c}0.528 \\
\left(5.021^{*}\right)\end{array}$ & $\begin{array}{c}0.373 \\
\left(4.159^{* *}\right)\end{array}$ & $\begin{array}{c}-0.080 \\
\left(-0.948^{* *}\right)\end{array}$ & 0.621 \\
\hline All years & 435 & $\begin{array}{c}0.402 \\
\left(6.880^{* *}\right)\end{array}$ & $\begin{array}{c}0.526 \\
\left(13.627^{* *}\right)\end{array}$ & $\begin{array}{c}-0.063 \\
(-1.185)\end{array}$ & 0.640 \\
\hline
\end{tabular}

${ }^{* *}$ Significant at less than 0.01 .

\subsection{Test of Possible Effect of the Sign of Other Comprehensive Income}

To test for any possible effect of the sign of other comprehensive income on the results reached on previous subsections, we partitioned the total sample into two subsamples: (1) positive other comprehensive income firmssubsample of 271 observations, and (2) negative other comprehensive income firms-subsample of 164 observations and re-examine the association between market price and net income per share and comprehensive income per share.

Panel A of table 6 presents the regression results based on the sign of other comprehensive income. It compares the explanatory power of net income per share and comprehensive income per share for the two subsamples. The

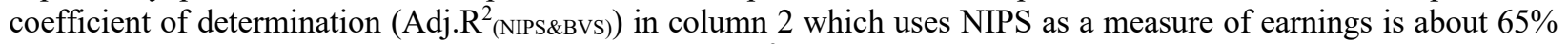
and $61 \%$, while the coefficient of determination (Adj. ${ }^{2}{ }_{\text {(CIPS\&BVS) }}$ ) in column 5 which uses CIPS as a measure of earnings is about $61 \%$ and $62 \%$ for the two subsample, subsequently. The valuation model explains more (less) of the variation of stock prices when net income per share (comprehensive income per share) is used as a measure of earnings in both subsamples.

The results for the incremental explanatory power for the two measures of earnings presented in columns 4 and 7 show that the incremental explanatory power of NIPS is about $8 \%$ and $5 \%$ whereas, the incremental explanatory power of CIPS is about $4 \%$ and $3 \%$ for the two subsamples, consequently. 
Panel B presents the results of the expanded model that adds other comprehensive income as an additional independent variable to the valuation model for the two subsamples. It shows that the coefficient of OCIPS is negative and insignificant which confirms the results obtained earlier for the total sample in the previous subsection.

The coefficient of determination Adj. $\mathrm{R}^{2}$ (NIPS, BVS, OCIPS) for the positive OCI items and the negative OCI items subsamples are $65 \%$ and $63 \%$, respectively. Comparing these results with those presented in Panel A of $65.1 \%$ and $63.1 \%$ for the original valuation model that uses book value and net income per share as explanatory variables reveals that adding other comprehensive income per share as an extra explanatory variable to the valuation model has no significant effect on its explanatory value.

The overall results from table 6 support the superiority of net income per share over comprehensive income per share in equity valuation regardless of the sign of other comprehensive income. Other comprehensive income does not add value to the valuation model.

Table 6. Tests for the Effect of the Sign of Other Comprehensive Income on the Value Relevance of Comprehensive Income

Panel A: The Association Results based on the Sign of Comprehensive Income

\begin{tabular}{|c|c|c|c|c|c|c|}
\hline Sub Sample & Adj.:R ${ }^{2}$ NIPS\&BVS) & $\operatorname{Adj.}^{2}{ }_{(\mathrm{NIPS})}$ & Incr. NIPS & Adj.:R ${ }_{(\text {CIPS\&BVS) }}$ & $\operatorname{Adj.}^{2}{ }_{(\text {CIPS })}$ & Incr. CIPS \\
\hline Positive OCI Firms & 0.651 & 0.517 & 0.082 & 0.610 & 0.393 & 0.041 \\
\hline Negative OCI Firms & 0.631 & 0.451 & 0.048 & 0.615 & 0.270 & 0.032 \\
\hline
\end{tabular}

Panel B: Tests for the effect of the Sign of Other Comprehensive Income on the Expanded Model The Model:

\begin{tabular}{|c|c|c|c|c|c|}
\hline \multicolumn{6}{|c|}{$P P S_{i t}=c_{0}+c_{1} N I P S_{i t}+c_{2} B V S_{i t}+c_{3} O C I P S_{i t}+e_{i t}$} \\
\hline Sub Sample & $\mathbf{N}$ & $\mathbf{C}_{1}$ & $\mathbf{C}_{2}$ & C3 & $\begin{array}{c}\text { Adj. } \mathbf{R}^{2} \\
\text { (NIPS\&BVS,OCIPS) }\end{array}$ \\
\hline Positive OCI Firms & 271 & $\begin{array}{c}0.388 \\
\left(8.010^{* *}\right)\end{array}$ & $\begin{array}{l}0.498 \\
\left(9.843^{* *}\right)\end{array}$ & $\begin{array}{c}-0.009 \\
(-0.229)\end{array}$ & 0.650 \\
\hline Negative OCI Firms & 164 & $\begin{array}{c}0.299 \\
\left(4.698^{* *}\right)\end{array}$ & $\begin{array}{c}0.554 \\
\left(8.312^{* *}\right)\end{array}$ & $\begin{array}{c}-0.036 \\
(-0.713) \\
\end{array}$ & 0.630 \\
\hline
\end{tabular}

\section{SUMMERY AND CONCLUDING REMARKS}

The study questions the usefulness of reporting comprehensive income to current and potential investors. It specifically examines whether comprehensive income reported under current IFRS has value relevance over net income in equity valuation. The study uses a sample of Kuwaiti firms belonging to banking, investment, real estate, industrial, basic materials, telecommunications, consumer services, oil \& gas and health care sectors that are listed in Kuwait Stock Exchange during years 2012-2015.

To achieve this, two approaches have been used. The first one compares the overall value relevance of two versions of Ohlson's model, the first version uses net income per share and book value per share and the second uses comprehensive income per share and book values per share as explanatory variables for stock prices.

The coefficient of determination (adjusted $\mathrm{R}^{2}$ ) as a metric measure of the overall value relevance for the two competing versions as well as the incremental explanatory power that each measures of earnings contributes to the total value relevance were compared. We found that the coefficient of determination for the first version exceeds that of the former and the incremental explanatory power of net income per share is higher than that of comprehensive income per share. These results reveal the superiority of net income per share over comprehensive income per share in equity valuation.

Secondly, we use an expanded version of Ohlson's model by adding other comprehensive income per share as a third explanatory variable to the valuation model and examine if it will enhance its explanatory value. We found that there was no change in the coefficient of determination for the valuation model. Adding other comprehensive income per share as an additional independent variable to the valuation model did not increase the overall value relevance of the model. The results show further that the coefficient of other comprehensive income in the expanded model was 
negative and insignificant at any acceptable level during the study period. This finding demonstrates further that other comprehensive income does not add to the overall value relevance of the model.

The finding of the two approaches asserts that net income number is superior to comprehensive income as a measure of performance in explaining the changes in share prices and hence it is more relevant in stock valuation.

The study has some limitations. First, it uses only four years' data in the sample. Second, it uses data from only one emerging capital market, and third it investigates the value relevance of other comprehensive income as an aggregate number due to the difficulty of obtaining data about its five components. Future research might examine and compare the value relevance of other comprehensive income using data from different capital emerging markets and over a longer period of years.

Despite the study limitations, its findings contribute to the literature of assessing the value relevance of the current financial performance reporting under IFRS generally and more specifically to the field of empirical studies on the relevance of other comprehensive income in emerging capital markets.

\section{AUTHOR BIOGRAPHIES}

Mostafa Elshamy, PhD., received his PhD in 1989 from Stern School of Business, New York University, USA. His area of research focuses on financial reporting, capital market-based research in accounting, and performance evaluation. He is the contact Author. E-mail: elshamy@cba.edu.kw

Husain Y. Alyousef, PhD., earned his PhD from University of Texas-Arlington (2006) in Accounting Information Systems. His research interest includes financial accounting, corporate governance and accounting information systems. E-mail: halyousef@cba.edu.kw

Jassem Al-Mudhaf, PhD., Received his PhD from Birmingham University (1983). He was the Dean of CBA from 2014-2016 and the chairman of the Accounting Department from 2010-2014. He has served as consultant for several Kuwaiti Organizations. His research interest includes financial accounting, accounting for financial institution and taxation. E-mail: jcc@cba.edu.kw

\section{REFERENCES}

Barton, J., Hansen, T. \& Pownall, G. (2010). Which Performance Measures Do Investors Around the World Value the Mostand Why? The Accounting Review, 85(3), 753-789.

Biddle, G. \& Choi, J. (2006). Is Comprehensive Income Useful? Journal of Contemporary Accounting \& Economics, $2(1)$, 1-32.

Chambers, D., Linsmeier, T., Shakespeare, C. \& Sougiannis, T. (2007). An evaluation of SFAS No. 130 comprehensive income disclosures. Review of Accounting Studies, 12(4), 557-593.

Collins, D., Maydew, E. \& Weiss, I. (1997). Changes in the value-relevance of earnings and book values over the past forty years. Journal of Accounting and Economics, 24(1), 39-67.

Collins, D., Pincus, M. \& Xie, H. (1999). Equity Valuation and Negative Earnings: The Role of Book Value of quity. The Accounting Review, 74(1), 29-61.

Dhaliwal, D., Subramanyam, K. \& Trezevant, R. (1999). Is comprehensive income superior to net income as a measure of firm performance? Journal of Accounting and Economics, 26(1-3), 43-67.

El Shamy, M. \& Kayed, M. (2005). The value relevance of earnings and book values in equity valuation: An international perspective - The case of Kuwait. International Journal of Commerce and Management, 15(1), 68-79.

El Shamy, M., Al-Hajri, M. \& Al-Bassam, S. (2014). The value relevance of unrealized gains and losses recognized under IAS 39. International Journal of Commerce and Management, 24(4), 355-366.

Feltham, G. \& Ohlson, J. (1995). Valuation and Clean Surplus Accounting for Operating and Financial Activities. Contemporary Accounting Research, 11(2), pp.689-731.

Financial Accounting Standards Board (FASB). 1997. Reporting Comprehensive Income. Statement of Financial Accounting Standards No. 130. Norwalk, CT: FASB.

Hirst, D. \& Hopkins, P. (1998). Comprehensive Income Reporting and Analysts' Valuation Judgments. Journal of Accounting Research, 36, p.47.

International Accounting Standard Board (2003 revised), International Accounting Standard IAS 16: Property, Plant and Equipment. London, U.K: IASC. 
International Accounting Standard Board (2005 revised), International Accounting Standard IAS 39: Financial Instruments: Recognition and Measurements. London, U.K: IASB.

International Accounting Standard Board (revised 2003), International Accounting Standard IAS 21: The Effects of Changes in Foreign Exchange Rates. London, U.K: IASB.

International Accounting Standard Board (2014), International Financial Reporting Standard IFRS 9: Financial Instruments. London, U.K: IASB.

International Accounting Standard Board (revised 20007), International Accounting Standard IAS 1: Presentation of Financial Statements. London, U.K: IASB.

International Accounting Standard Committee (1994 reformatted), International Accounting Standard IAS 26: Accounting and Reporting by Retirement Benefit Plans. London, U.K: IASC.

Jones, D. \& Smith, K. (2011). Comparing the Value Relevance, Predictive Value, and Persistence of Other Comprehensive Income and Special Items. The Accounting Review, 86(6), 2047-2073.

Kanagaretnam, K., Mathieu, R. \& Shehata, M. (2009). Usefulness of comprehensive income reporting in Canada. Journal of Accounting and Public Policy, 28(4), 349-365.

Lee, Y., Petrroni, K. \& Shen, M. (2006). Cherry Picking, Disclosure Quality, and Comprehensive Income Reporting Choices: The Case of Property-Liability Insurers. Contemporary Accounting Research, 23(3), 655-692.

Lin, S., Martinez, D. \& Wang, C. (2016). Is Other Comprehensive Income Reported in the Income Statement More Value Relevant? The Role of Financial Statement Presentation. Journal of Accounting, Auditing \& Finance, 33(4), $624-646$.

Maines, L. \& McDaniel, L. (2000). Effects of Comprehensive-Income Characteristics on Nonprofessional Investors' Judgments: The Role of Financial-Statement Presentation Format. The Accounting Review, 75(2), 179-207.

Ohlson, J. (1995). Earnings, Book Values, and Dividends in Equity Valuation. Contemporary Accounting Research, 11(2), 661687.

Pronobis, P. \& Zülch, H. (2010). The Predictive Power of Comprehensive Income and its Individual Components Under IFRS. SSRN Electronic Journal. 9(4).

Rees, L. \& Shane, P. (2012). Academic Research and Standard-Setting: The Case of Other Comprehensive Income. Accounting Horizons, 26 (4), 789-915.

Theil, H. (1971). Principles of Econometrics. New York, NY: Wiley. 